\title{
LEGISLATIVE HISTORY AS AN INTERPRETATIVE TOOL IN UNI- AND MULTINLINGUAL LEGAL SYSTEMS (BASED ON THE EXAMPLE OF POLAND AND THE UE)
}

AGNIESZKA BIELSKA-BRODZIAK

Katedra Teorii i Filozofii Prawa Uniwersytet Śląski

ul. Bankowa 11b, 40-007 Katowice xbb@ interia.pl

\section{KAROLINA PALUSZEK}

Instytut Prawa, Administracji i Zarządzania Uniwersytet Humanistyczno-Przyrodniczy im. Jana Długosza

ul. Zbierskiego 2/4, 42-200 Częstochowa paluszek.karolina@gmail.com 
Abstract: The paper aims to analyse and compare the interpretative function of legis lative history in the judicial activity of the European Court of Justice and Polish courts.

The authors have analysed judgments of the respective courts, focusing on the role of legislative history in their argumentation. In the Polish and European doctrine, the usefulness of travaux preparatoires has been underestimated. Nevertheless, legis lative history may provide arguments important in judicial reasoning both in uni- and multilingual legal systems. However, its importance and functions in Polish and European cases examined herein are different. The research conducted enables a better understanding of the interpretative value of legis lative history in legal interpretation and can result in more frequent use of this tool in the judicial activity of national and European courts.

Keywords: legis lative history, legal interpretation, multilingual law

\title{
„HISTORIA LEGIS LACYJNA” JAKO NARZĘDZIE WYKŁ ADN I JEDNO I WIELOJĘZYKOWYCH SYSTEMÓW PRAWNYCH (NA PRZYKLADZIE POLSKI I EU)
}

\begin{abstract}
Abstrakt: Celem pracy jest analiza i porównanie interpretacyjnego znaczenia historii legislacyjnej w działalności orzeczniczej Europejskiego Trybunału Sprawiedliwości i sądów polskich.

Autorki analizują orzeczenia sądów, koncentrując się na roli historii legislacyjnej w używanej przez sądy argumentacji. W doktrynie polskiej i europejskiej użyteczność travaux preparatoires nie jest dostatecznie doceniana. Niemniej jednak historia legislacyjna może dostarczyć w procesie wykładni tekstu prawnego istotnych argumentów i to zarówno w jednojęzycznych, jak i wielojęzycznych systemach prawnych. Jednak jej znaczenie i funkcje w obu badanych jurysdykcjach są odmienne. Przeprowadzone badania pozwalają na lepsze zrozumienie wartości interpretacyjnej materiałów legislacyjnych w interpretacji prawniczej i mogą przyczynić się do zwiększenia użyć tego narzędzia w działalności sądowej sądów krajowych i europejskich.
\end{abstract}

Słowa klucze: historia legislacyjna, wykładnia prawa, wielojęzyczność prawa 


\section{What is legislative history? Several remarks on its position in legal interpretation around the world, including arguments in favour of and against legislative history usage $^{1}$}

The legal interpretive discourse offers tools which are significant in some of the legal systems and are at the same time undervalued in others. An excellent corroboration of this thesis can be found in legislative materials, a set of documents drawn up in the process of creating a piece of legislation, making up the so-called legislative history of a piece of legislation. Legislative materials, treated as a potential tool in the interpretation of the law, have arguably been one of the most discussed issues in worldwide legal theory over the past few years. The discussion on ways of using legislative materials and the role they play or should play in the interpretation of the law is taking place in numerous countries across Europe (Germany, Sweden, Great Britain, France, Spain), but also outside the European culture (in the United States, which not only started this discussion, but in fact continues to keep it on a very high level, as well as in Australia, Canada, New Zealand, or Asian countries) $)^{2}$. The ongoing debate, which involves not just interpreters, but also the legislature ${ }^{3}$, is a trigger for discussions on the value of legislative materials for interpretation of the law. Legislative materials (also referred to as preparatory materials or travaux preparatoires) usually appear in the context of interpretation of the law under the name legislative history. The term was coined in English language literature, where its use is widespread ${ }^{4}$. Conventionally understood, legislative history is a set of materials drawn up in the form of documents - produced by the legislator or

\footnotetext{
1 Project financed by the Polish National Science Centre under grant no. DEC2011/03/D/HS5/02493.

${ }^{2}$ I discuss this in more detail in monograph A. Bielska - Brodziak, Śladami prawodawcy faktycznego. Materiaty legislacyjne jako narzędzie wykładni, Warsaw 2017.

${ }^{3}$ See e.g. a comprehensive and detailed study conducted in the legislative circles, described in a two-part work by A. R. Gluck, L. S. Bressman (2013: 901-1025 and 2014: 725-801).

${ }^{4}$ Legislative history is a highly popular term in English language literature - cf. e.g Popkin 2007: 160-183; also Eskridge Jr, Frickey and Garrett 2006: 303.
} 
commissioned by the legislator in the course of drafting and passing of a piece of legislation, with documents deriving from the parliamentary stage of the law-making process being the most important for the process of interpretation of the law. Legislative history is used in the process of interpretation with the interpreter accessing draft acts, explanatory statements, or parliamentary debate records in order to develop, accept, or reject interpretative hypotheses.

\section{Poland}

\subsection{Types of legislative materials and the evolution of their value resulting from improved access to legislative history (the Internet)}

Legislative materials can be divided into three categories, reflecting the stages of the law-making process: materials created before submitting the draft legislation to the parliament, materials created during the parliamentary phase, and presidential veto (which is rarely and marginally important for the interpretation process). Materials of the pre-parliamentary phase (naturally, with the exception of the draft itself and the explanatory statement) have so far had rather limited significance for interpretation, which is not to say that it should be like that. Especially in case of drafts authored by the government, the knowledge of legislative circumstances that emerged during the work on the draft can be invaluable for the interpretation process. The use of legislative materials generated before the draft had been referred to the parliament, ought to increase not just because the information included therein is useful, but also because it is readily available.

Some of the most useful and most frequently used legislative materials are documents drawn up in the course of work of the Sejm and Senate, namely:

1. explanatory statements to bills 
2. amendments submitted in the course of the legislative works (both those which resulted in modification of the draft and those which were rejected) by the Sejm and Senate committees

3. committee and subcommittee reports being updated versions of the bill (approved by vote in the various stages of the subsequent stages of the legislative procedure)

4. stenographic records of debates held as part of committee or subcommittee works, or as part of plenary sessions of the legislative body

5. opinions on the draft.

All these materials are currently readily available for interpreters in the public space. More detailed issues, important for the interpreter and related to the various types of legislative materials, will not be discussed herein given the assumed framework of this article 5 .

It must be emphasised that over the past few years the conditions of using legislative materials have significantly improved due to free, relatively easy, and convenient access via the Internet. Poland currently has several official databases which offer on-line access to legislative materials.

\subsection{Ways of using legislative materials in decisions of Polish courts}

Two areas should be distinguished here. The first one is reasons for using legislative history in the process of interpretation (what is the interpreter trying to find?), whereas the second one is specific interpretation situations (interpretation problems), wherein legislative materials prove useful (what problem is the interpreter trying to solve?).

\footnotetext{
${ }^{5}$ I have discussed these in my monograph (Bielska-Brodziak, 2017) so I encourage the Readers to refer to the book.
} 


\subsubsection{Reasons for using legislative materials in interpretation of the law (what are we trying to find?)}

Regardless of what problem the interpreter is working on, the legislative history can be used either to find information on the legislator's objective or on the meaning (of a particular word/phrase used in the wording of a provision of the law) ${ }^{6}$. In the first case, explanatory statements to bills will mostly be used, as this type of documents includes an explanation of the motives behind the legislator's lawmaking activity. It is worth noting that determination of the objective is the prevailing reason for referring to legislative materials in decisionmaking practice. Using legislative history in this way also appears to be in accordance with the legal intuition: analysis of the comprehensive background for a bill and conditions of the debate that precedes its entry into force, all of which can be extracted from legislative history, offers an opportunity to understand the context behind the legislator's activity and the objectives of the actual legislator (Breyer 1992: 848).

On the other hand, legislative materials can also be used as a dictionary, which the interpreter uses to look up the meaning of a certain word or phrase used in an act. Identification of the meaning of a specific word or phrase calls for using different types of parliamentary documents. In this case, the best way to obtain information is through the observation of changes in a provision of the law resulting from amendments adopted, and through an analysis of amendments rejected (which, in turn, reveal what the legislator did not want). This will involve both draft modifications implemented through amendments (elimination of certain wording, introduction of other modifications to the existing wording of the draft), as well as explanatory statements to the amendments. Moreover, information can be found in opinions on the draft, including the reaction of the Sejm bodies to these opinions (whether they have been taken into account or ignored). It is worth adding that when looking for information on the meaning of a particular word of expression used by the legislator, a single legislative material

\footnotetext{
${ }^{6}$ Numerous publications in the English language highlight the two aforementioned reasons for using legislative materials. See e.g. Nourse (2014: 1644); Jellum (2008: 169). Similar distinctions are made in the German literature - see Übelacker (1993: 1417).
} 
is seldom used. Instead, interpreters usually carry out more comprehensive analyses of numerous documents.

\subsubsection{Problems (interpretation situations) sol ved with the help of legislative history}

The second sphere in which legislative history is used for interpretation purposes is connected with its usefulness for solving specific situations or interpretation problems (ambiguity, vagueness, silence on the part of the legislator, etc.). Legislative materials are used in interpretation of the law in five interpretation situations: choosing from among several interpretation hypotheses, confirming a specific interpretation, supplementing the meaning of the interpreted phrase, interpretation against the wording, and silence on the part of the legislator ${ }^{7}$.

To start with, argument from legislative materials is invoked as a justification of choice from among several possible interpretations of a text. This usage will be characteristic for solving the problem of ambiguity of legal texts: "Since the linguistic interpretation of this phrase does not lead to an unambiguous meaning, the ratio legis of the amended provision under interpretation must be determined (...)."

Using legislative history in order to choose from among several interpretation hypotheses appears to be the least controversial usage of this tool ${ }^{9}$. The choice has to be made when the interpreter is dealing with ambiguous wording of a provision of law ${ }^{10}$ or with the so-called

\footnotetext{
${ }^{7}$ This has been discussed more broadly in Bielska - Brodziak 2017: chapter 5.

${ }^{8}$ The Supreme Court further used the explanatory statement to the governmental draft of the bill, see Cf. Supreme Court resolution of 26 April 2017, I KZP 7/07, OSNKW 2007/5/38. See also Solan (2005: 484).

${ }^{9}$ That said, the scholars are not unanimous even about the admissibility of this usage see a comparison of views held by Scalia and Breyer on the acceptable ways of using legislative history in the interpretation of law described by Mammen (2002: 155 et seq., 169 et seq.)

${ }^{10} \mathrm{~A}$ frequent problem when a choice has to be made is a conflict between the so-called "plain" meanings, inferred from the general ("colloquial") language, "In a case where various provisions of the text suggest two completely different «plain» meanings, a tiebreaking device is necessary. Legislative history can be such a device (...)" - Zeppos
} 
classification $^{11}$. Whenever this is the case, referring to legislative materials makes it possible to select one of severalmeanings of a legal text and reject the other ones.

Secondly, legislative history is often employed to confirm a line of interpretation ${ }^{12}$. In many judgments, this argument merely serves to strengthen and provide a better justification for an interpretation hypothesis, or to ensure that it is correct ${ }^{13}$. Nevertheless, the confirming function of parliamentary documents is not limited to merely strengthening argumentation for a specific, previously selected interpretation hypothesis. In fact, it frequently becomes a litmus paper for clarity as in many cases a prima facie unambiguous text, once it has been analysed in the context of its legislative history, loses its clarity ${ }^{14}$.

The third way of using legislative materials is the so-called supplementation. The justification for this function of legislative materials is the conviction that the legislator has included in them a number of hints for the interpreters - for instance hints on how to construe details which have not been expressly set out in the text - and so they can be treated as a vehicle for conveying these additional details (Gluck and Bressman 2013: 973). In order to correctly interpret a text, one sometimes needs to simply supplement it with these details. The most recognised category of problems where interpreters recourse to

(1990:1328). In Polish literature on ambiguity in law see Gizbert-Studnicki 1978. More recently, important observations, from an intentionalist position, have been presented by Tobor (2013: 153-189).

${ }^{11}$ This is an interpretation situation in which the interpreter must decide whether a case is an element of a specific legal category (e.g. the famous American case, where it had to be determined whether a tomato is a vegetable or a fruit, and the decision was important for the level of taxation to be applied). Naturally, this decision entails that certain effects, as provided for by the law, will or will not be applied. On classification as a separate type of interpretation situations, see Tobor (2013: 213-223); Grabowski 1997: 85-89. In foreign literature, see MacCormick (1978: 95-97 and 147-148).

12 The confirmatory function of legislative materials has been analysed in Brudney (2011: 901 et seq).

${ }^{13}$ Judgment of the Voivodeship Administrative Court in Krakow of 28 November 2013, I SA/Kr 1222/13, LEX No. 1485017. Other examples of judgments: judgment of the Voivodeship Administrative Court in Krakow of 6 June 2013, I SA/Kr 1903/12, LEX No. 1333935; judgment of the Supreme Administrative Court in Warsaw of 26 February 2013, I FSK 491/12, LEX No. 1354026.

${ }^{14}$ On how a text's clarity and ambiguity depends on the context see Mammen (2002: 33-37); Nourse (2014: 1650 et seq). 
legislative history in order to "supplement" the meaning is vagueness ${ }^{15}$. The job of the interpreter is then to decide whether a case he or she is considering can be qualified as a vague expression (in other words, whether it falls within the meaning of vagueness $)^{16}$.

The fourth situation where lawyers recourse to legislative materials is when they interpret against the wording. This encompasses cases when the linguistic meaning of a legal text is clear, however the interpreter rejects it, and decides in defiance of it (in such cases decisions are taken based on a meaning which contradicts the wording of a provision, and which does not follow from the letter of the law). Interpretation against the wording is in fact correcting, amending, and refining the text of an act through interpretation. Therefore, the interpreter accepts fiction and decides as if the wording of the act was different. The justification for the need to breakfrom the literal meaning is usually the conviction that the legislator made a mistake when drawing up the act, as a result of which following the linguistic meaning would lead to absurd, flagrantly unjust or otherwise unacceptable consequences. One of the judgments reads as follows:

an unintentional legis lative error took place, causing a gap in the provision (...) as a result of which application of the norm derived from the literal wording of the provision is unacceptable as it manifestly contradicts the principle of reasonableness and equity. ${ }^{17}$

This is arguably the most interesting category of uses of legislative materials. Derogations from the linguistic meaning are the most controversial interpretation situations and, considering the uncertainty that they entail, raise concerns among the addressees of the decision implementing the law ${ }^{18}$. In the light of the deeply ingrained

\footnotetext{
${ }^{15}$ Given that there is an extensive literature on vagueness, I shall only refer to selected publications: Greenawalt (2001: 433 et seq.); Edincott (2011: 14-30); Jónsson (2009: 193-214).

${ }^{16}$ For instance, whether a case of negligence can be considered as "gross", or whether some remuneration can be considered as "excessive", etc. For more details on this, Łętowska (201: 17).

${ }^{17}$ Cf. Supreme Court resolution of 25 February 2009, I KZP 39/08

${ }^{18}$ This is especially the case when breaking from the literal meaning causes negative consequences for the citizen.
} 
belief that the limits of the law are defined by "the four corners of a sheet of paper"19, such manifest cases of derogating from the letter of the law attract attention of both interpretation practitioners and legal scholars specialising in interpretation ${ }^{20}$. If breaking from the literal meaning is inevitable, it appears that legislative materials ought to provide the strongest justification for the decision to do so: the context created by legislative history, which comes directly from the legislator, seems to best justify departing from the imperfect language of the act.

It is also worth adding that legislative materials are used in case of silence on the part of the legislator. The legislator's silence, or the absence of a clear wording of an issue in a legal act, is always performative and entails interpretation consequences. Legislative materials are used to determine whether the legislator purposefully or accidently did not include some wording in the text of an act, and as a result, to attribute meaning to this silence ${ }^{21}$.

\subsection{The role of legislative materials in Polish interpretative paradigm in Polish literature and decision-making practice}

Poland has not introduced, either statutorily or through established interpretation directives, any rules for using legislative materials. Therefore, there are no directives requiring or prohibiting using them. As a general rule, the Polish legal tradition has allowed the use of any and all materials which may prove useful in the course of interpretation of the law, although it is obvious that some interpretation tools will be more culturally valued and recommended than others. The use of

\footnotetext{
${ }^{19}$ Z. Tobor (2013: 232) indicates, however, that "contemporary textualists have given up the conviction that meaning can be determined within the four corners of a legal text". See also C. Nelson (2005: 368-369).

${ }^{20}$ Opponents of breaking from the literal wording of an act maintain that acts ought to be construed in line with their plain or conventional meanings, and - in the event of a conflict of meanings - the plain, linguistic meaning ought to prevail over other possible interpretations - B. Bix (1996: 132).

${ }^{21}$ A number of highly interesting cases illustrating different situations where legislative materials were used have been described in my monograph (Bielska-Brodziak 2017). The Readers may want to look them up.
}

16 
travaux preparatoires in the process of interpretation of the law has, until recently, only received marginal interest in the Polish literature, and yet - as shown by the analyses conducted above - their popularity in judicial decision making surprises by its scale. It is beyond any doubt that legislative materials are currently an important and increasingly used interpretation tool. It should be emphasised that this is partly due to the fact that over the past few years the conditions of using legislative materials have significantly improved owing to free, relatively easy and convenient access via the Internet.

\section{Interpretation of EU law}

\subsection{Introduction - specificities of EU legal order influencing the courts' approach towards legislative history ${ }^{22}$}

As was the case with Poland, the role of legislative history in the EU context did not attract the attention of a vast majority of legal scholars. The usefulness of various tools of historical interpretation (proposals and drafts of legal acts, minutes from consultation proceedings, but also amendments and changes to the enacted legislation) for interpretation of European law context tends to be questioned, without a comprehensive analysis of the issue. Several reasons for the marginal importance of historical interpretation have been pointed out by $\mathrm{N}$. Reich (2004: 26-27):

1. The complexity and length of the EU legislation procedure;

2. Rich diversity of national legal traditions in the EU.

\footnotetext{
${ }^{22}$ The research presented in this paper is part of the project: "Linguistic comparison as an interpretative tool of the Court of Justice of the European Union", financed by the Polish National Science Centre (agreement no. UMO-2014/13/N/HS5/01278). A more complex analysis of linguistic comparison within historical interpretation has been presented as part of doctoral thesis of K. Paluszek, written in Polish, entitled "Komparaty styka języ kowa jako narzędzie interpretacyjne Trybunału Sprawiedliwości Unii Europejskiej), Katowice 2017, yet unpublished (see chapter IV)
} 
Prohibition of using declarations of the Commission or Council in interpretation against the wording of the interpreted provision, derived from the EU case law The marginal use of historical interpretation remains in line with the ECJ case law, according to which the use of historical interpretation, and above all legislative materials, is subject to significant limitations ${ }^{23}$. The Court points out that the reference to the course of the legislative process cannot lead to an interpretation which is contrary to the wording of the interpreted provision ${ }^{24}$. Although the acceptance of such "linguistic borders" of interpretation raises serious doubts ${ }^{25}$ (especially with regard to the extensive advocacy for the adoption of the principle of dynamic interpretation, which assumes a widespread use of non-textual directives of interpretation), it should be admitted that the usage of the legislative history does not play a crucial role in the judicial practice of the CJEU. However, the growing importance of historical arguments has been noticed in literature - K. Lenaerts and J.A. Gutiérrez-Fons (2013: 24), S. Schønberg and K. Frick (2003: 149) as well as S. Miettinen and M. Kettunen (2005). S. Schønberg and K. Frick (2003: 149) distinguish different reasons for the change of attitude of the CJEU towards travaux preparatoires (influence of national legal traditions of member states, complex and technical nature of interpreted acts, improving quality and accessibility of legislative materials).

This article does not aim to present a comprehensive analysis of the use of historical arguments by the Court of Justice. Instead, it focuses on displaying some original features of the EU law (in comparison with national, often monolingual legislation) that can contribute to a greater usefulness of legislative materials in the process of its interpretation.

\footnotetext{
${ }^{23}$ Judgment of the Court of 23.02. 1988 r. in case 429/85 Commission v Italy, Rec. p. 843, point. 9 and Judgment of the Court of 10.01.2006 in case C- 402/03 Skov Æg v Bilka Lavprisvarehus A/S and Bilka Lavprisvarehus A/S v Jette Mikkelsen and Michael Due Nielsen (ECLI:EU:C:2006:6) point 42. Such position remains also in accordance with the legal culture of common law countries - see Bielska-Brodziak (2012: 144-154).

${ }^{24}$ Judgment of the Court of 26.02.1991r. in case c-292/89 The Queen v Immigration Appeal Tribunal, ex parte Gustaff Desiderius Antonissen (ECLI:EU:C:1991:80), point 18

${ }^{25}$ It has been stated that such "linguistic borders" of the interpretation do not exist - see A. Bielska-Brodziak 2006, Spy ra 2006, Tobor (2010: 194-201).
} 


\section{a. The lawmakers' participation in proce edings before the CJEU}

Unlike by national legislation, the reconstruction of the course of legislative works in case of the EU law is facilitated by the fact that the EU legislative bodies have the right to participate in proceedings before the Court. In most direct action proceedings, the EU institutions (including its legislative bodies and the Commission, which owns the legislative initiative) are parties. Additionally, in preliminary proceedings, under Art. 23 of the Statute of the CJEU, an institution, body, office or agency of the Union which adopted an act the validity or interpretation of which is in dispute (as well as the Commission), shall be entitled to submit to the Court written pleadings or written observations ${ }^{26}$. A similar provision is contained in the Rules of Procedure of the Court (Article 96\$1), according to which the institution which issued the act, validity or interpretation of which is the subject of the dispute, may also be involved in the preliminary ruling proceedings.

Therefore, it is possible to confront various views on the course of legislative work and the presumed intentions of the legislator with the view of the institutions that actually worked on the interpreted act (both at the proposal stage and on the finally adopted project). As regards the interpretation of primary law, it should be noted that unlike the secondary EU legislation, primary law includes international agreements concluded between the Member States. Consequently, not only the EU Institutions but also the Member States are involved in the process of drafting and changing them. Thus, in the case of primary legislation, there are more entities involved in the legislative process. Member States are also involved in proceedings before the Court (where they can act as parties or intervene on a similar basis as EU institutions). Nevertheless, the multiplicity of actors involved in the adoption and amendment of primary legislation, as well as the

\footnotetext{
${ }^{26}$ Consolidated text annexed to the Treaties of the Protocol (No 3) on the Statute of the Court of Justice of the European Union, as amended by Regulation (EU, Euratom) of the European Parliament and of the Council No 741/2012 of 11 August 2012 (OJ L 1) and Article 9 of the Act concerning the conditions of accession of the Republic of Croatia and the adjustments to the Treaty on European Union, the Treaty on the Functioning of the European Union and the Treaty establishing the European Atomic Energy Community (OJ L112 of 24.4.2012 21).
} 
differences in the interests they represent, make it more difficult (in comparison to secondary legislation) to obtain clear information about the course of the legislative process and the intention of the lawmaker in proceedings before the ECJ. Using arguments based on the legislative history in the interpretation of primary law is further complicated by the fact that initially the preparatory works were not preserved. This was pointed out by Advocate General Kokott in her opinion in case C583/11, where she noted a significant turning point in recourse to historical directives in the interpretation process:

Drafting history in particular has not played a role thus far in the interpretation of primary law, because the 'travaux préparatoires' for the founding Treaties were largely not available. However, the practice of using conventions to prepare Treaty amendments, like the practice of publishing the mandates of intergovernmental conferences, has led to a fundamental change in this area. The greater transparency in the preparations for Treaty amendments opens up new possibilities for interpreting the Treaties which should be utilised as supplementary means of interpretation if, as in the present case, the meaning of a provision is still unclear having regard to its wording, the regulatory context and the objectives pursued. ${ }^{27}$

As is clear from this passage, reference to the course of the legislative process may be relevant in situations where the interpretative problem concerns primary law. A similar role of legislative materials can be observed in the interpretation of secondary law. Even accepting the prohibition of an interpretation contrary to the wording (which is significantly weakened by multilingualism) does not mean that legislative materials cannot be used at all in the course of interpretation, for example initiating the process or supporting the result obtained by other interpretative methods.

${ }^{27}$ Opinion of Advocate general J. Kokott delivered on 17.01.2013 in case C-583/11 P Inuit Tapiriit Kanatami and Others v European Parliament and Council of the European Union (ECLI:EU:C:2013:21) point 32

20 


\section{b. Multilingualism - a new chance for historical arguments}

Multilingualism is a feature of the EU law which has a significant impact on how the traditional interpretative methods and directives are used. Linguistic comparison comprises an analysis and collation of the wording of the contested provision of law in the official languages of the EU. It is often regarded as a part of textual analysis of the wording of contested provision (Wróbel 2010: 329, Kalisz 2007: 158, Barcik and Wentkowska 2014: 310, Kalisz 2011: 197) ${ }^{28}$. It reveals divergences between various language versions that have to be reconciled by nontextual methods of interpretation (first of all teleological and systemic). Historical interpretation has not been mentioned as useful in solving problems resulting from multilingualism. However, the multilingual nature of the EU law opens new possibilities for using this underestimated interpretative tool. Additionally, linguistic comparison, combined with historical arguments, may not only be regarded as a source of interpretative doubts, but also as a valuable instrument in finding a solution.

The link between historical interpretation and multilingualis $m$ is evident in the comparison of the multilingual wording of the historical versions of the interpreted legal act or related regulations, as well as in the use of the chronology of the formation of individual language versions in the course of interpretation. As previously shown, the Court has formulated a prohibition on using the course of the legislative process for interpretation contrary to the wording of the provision, which constitutes the limit to the use of historical arguments in the interpretation (albeit raises the previously stated doubts). Moreover, multilingualism of the EU law can also seriously limit the possibility of interpretation "contrary to the wording". Thus, in case of as many as 24 available language versions, the inconsistency of the interpretation with one version does not necessarily conflict with the other versions.

In addition, multilingualism makes it possible to compare the wording of proposals as well as the successive changes of interpreted

${ }^{28}$ However, M. Zirk-Sadowski (2012: 371) classifies "linguistic comparison" as a systemic directive of interpretation. 
provisions in different language versions of proposals or already enacted legal acts, which constitutes another valuable material used in the interpretation of the EU law alongside other interpretative tools. In the context of multilingualism, there is a particular argument that can be included in the broadly understood history of legislation. While legislative work can be carried out parallel in many languages, so that it is impossible to distinguish between drafting and translation of law (co-drafting) ${ }^{29}$, it is important to realise that this only applies to language versions authentic at the time of legislative work. However, the number of official languages of the EU, and thus the authentic languages of its legislation, is constantly changing (it has grown so far as with each EU enlargement, and could now hypothetically decrease as a result of the planned Brexit).

Consequently, in spite of accepted fictions, as described in literature (Doczekalska 2009: 359), and first of all despite treating all versions as equal originals, some language versions are inevitably secondary - resulting from the increase in the number of official languages of the EU as an effect of subsequent enlargements. It has been stated in the doctrine that the Court actually takes also those "subsequent" versions into consideration, ignoring the chronology of drafting particular versions ${ }^{30}$. Nevertheless, this statement does not seem to be illustrative of a general rule of rejection of chronology in the CJEU. On the contrary, the recent case law does not confirm the existence of obstacles in using the chronological arguments in cases decided by the CJEU. Consequently, in the course of proceedings a party, advocate general or the Court can refer to the wording of the "original language versions" existing at the time of the adoption or entry into force of the interpreted act. And although it is fair to believe that referring to the chronological priority of the language versions is contrary to the accepted principle of equal authenticity of all language versions, and above all the theory of original texts (according to which

\footnotetext{
${ }^{29}$ A. Doczekalska (2009: 359), referring to works of T. Gallas and M. Guggeis points out that the term "co-drafting" has been used in description of legislative proposal's verification conducted by lawyer-linguists (Doczekalska 2009: 359). The same author analyses various co-drafting techniques (2009: 116-135).

30 A. Doczekalska (2006: 19) provides an example of Judgment of the Court of 24.10.1996 in case C-72/95 Aannemersbedrijf P.K. Kraaijeveld BV e.a. v Gedeputeerde Staten van Zuid-Holland.
} 
all versions are treated as equal originals, and should be considered in course of interpretation even if they did not exist at the time of passing the interpreted act), this specific kind of historical considerations actually takes place in the CJEU adjudication process.

It should be emphasised that not only the wording of the judgment in a particular case matters for understanding the process of interpretation of the EU law, but also the advocate general's opinion, containing an analysis of the case and a proposal of the solution with a comprehensive justification prepared by a judge-like member of the Court. The final decision often remains in line with the opinion, but the justification is rather shorter and focuses on the main arguments, whereas others are summarized or passed over in silence. Therefore, also the opinions should be regarded as a valuable source of argumentation for the interpretative choices of the Court.

\subsection{Ways of using legislative materials by the Court of Justice}

Both aforementioned specific features of the EU law and adjudication process imply the different role of historical arguments in the course of interpretation (in comparison to the national legal system, where it is rather impossible to deal with more than twenty equally authentic language versions and to have the lawmaker represented in the proceedings). Therefore, it can be difficult to classify the roles that legislative history can play in categories proposed for the Polish law. As the purposive approach plays a crucial role in EU legal interpretation, we rather look for the lawmaker's intent instead of sticking to the meaning of particular words (especially dealing with many inequivalent words in different languages). However, the lawmaker's aim is usually articulated in the recitals to the legal act (rarely found in national legal acts), so it may be unnecessary to look into the act's proposal or its justification.

Of course in some cases the advocate general's opinion or the judgment contains references to the intention derived from travaux 
preparatoire $^{31}$ - in such cases their use does not differ much from how they are used in Poland.

Additionally, the lawmaker's attendance at the Court proceedings gives him the chance to explain his intent - as to what the lawmaker wanted to say and to achieve - and it may lead to reference to legislative history. In this way participants make use of the explanatory value of travaux preparatoires. For example, in case C193/11 the Commission stated that the text of the French language version to the interpreted directive was actually discussed and accepted by all member States ${ }^{32}$. It should be emphasised that, unlike in national settings, the core issue in raising such arguments is not the aim of the lawmaker or explaining the meaning of a specific unclear term, but rather the way to persuade the Court to reconcile the divergences between various authentic language versions in favour of the informal original. Similarly, the Court or advocate general do not search for the explanation of meaning of particular words in the way that national courts do. They rather try to determine which language versions and which words have been used in the course of the legislative procedure. This is a pre-step taking place before considerations of the meaning of disputed provision. It aims to identify what was originally said before the process of multiple translations started.

\subsection{Interpretative situations, the role of historical arguments and their value for the final solution}

The interpretative situations in legal interpretation are similar regardless of the legal system. However, in a multilingual setting, one additional feature must be considered that is the diverging language versions, often containing expressions of different meaning and scope. Therefore, the most important issue is the comparative analysis of

\footnotetext{
${ }^{31}$ See for example interesting considerations on the lawmaker's intention based on an analysis of travaux preparatoires (comparison of proposal and final text of the interpreted directive), presented by Advocate General P. Mengozzi in his opinion from 24.10.2012 in case c-409/11 Csonka and others v. Magyar Állam (ECLI:EU:C:2012:660), pp. 30-32

32 Judgment of the Court from 26.09.2013 in case C-193/11 European Commission against Republic of Poland (ECLI:EU:C:2013:608, point 15)
} 
different wordings that are supposed to mean the same thing. The single expressions may be ambiguous or vague, but they must be considered as constituting the same, equal legal provision. This issue of inconsistency might be recognised as a specific type of ambiguity or classification problem (as the particular versions often contain words of different scope). The situation of vagueness is less common.

The next function of legislative history arguments observed in Polish judgments, namely interpretation contrary to the wording is not so obvious to determine, as we deal with more than one text. As has already been stated, the legal interpretation of multilingual law requires taking into consideration different language versions of the interpreted act. In case of the EU law, we rather deal with inconsistent language versions than with interpretation contrary to the wording (that must consequently have been contrary to all, often diverging language versions). And even if such use of legislative history could be considered (with the aforementioned limitations), the stable position of the CJEU presented at the beginning suggests a rather weak chance for success of such argumentation.

The function of legislative history also differs from categories distinguished for the Polish adjudication process. The similar feature is that in many cases legislative history does not serve as the only or key interpretative tool but rather supports other arguments. But as has already been explained, legislative history serves rather at the beginning of the process of interpretation to limit the scope of further analysis and provide supplementary arguments than to verify the results of other interpretative methods ${ }^{33}$.

For instance, the time of origin of each language version influenced the range of linguistic comparison (number of versions tested) conducted by advocate general in case c-359/12 Timmel. In her opinion in Case c-359/12 Timmel, Advocate General E. Sharpston stated:

At the time when the Prospectus Directive entered into force (on 31 December 2003) there were 15 Member States and 11 official languages. In 10 of those languages the word 'and' is used in Article

\footnotetext{
${ }^{33}$ Nevertheless, such verify ing role can sometimes be observed, see opinion of advocate general P. Cruz Villalón from 06.10.2015 in joined cases c-443/14 and C-444/14 Kreis Warendorf v. Ibrahim Alo and Amir Osso v. Region Hannover (ECLI:EU:C:2015:665), point 49.
} 
14(2)(b) of the Prospectus Directive. The word 'or' is used only in the German version of the text. ${ }^{34}$

Surprisingly, after that short analysis (reported only in the footnote), the advocate general made reference to the need to compare all language versions (confirmed in the CJEU case law). The quoted passage shows that the moment of entry into force of the interpreted Directive has been used to limit the scope of linguistic comparison. Only versions existing in December 2013 have been examined, despite indications by the Advocate General, that all the language versions should be considered. In addition to the quantitative argument (interpretation in accordance with most language versions), the Advocate General referred to the scheme and purpose of the legislation at issue.

The Court shared the conclusions of Advocate General, stressing her teleological considerations ${ }^{35}$. However, in justification of the final decision, the Court did not refer to linguistic comparison and did not use quantitative arguments nor chronology of the formation of the various language versions.

In some disputes the chronology of the formation of the various language versions has been used both in the opinion of the Advocate General and in the Court's judgment. In case Confédération paysanne ${ }^{36}$ Advocate General J. Kokott had analyzed the meaning of all 11 original language versions of the interpreted Regulation, indicating the interpretation possibilities arising from the various versions. It should be emphasised that the opinion was written in May 2013, when the EU had 23 official languages - and all 23 versions of the interpreted act were equally authentic. However, the AG based her arguments only on the 11 versions, existing at the time of adoption of the interpreted act. She showed similarity of all examined language versions (despite the use of different formulations), with the exception of one. The observed similarity of all the original versions (except the French) then gave rise

\footnotetext{
${ }^{34}$ Opinion of Advocate General E. Sharpston delivered on 26.11.2013 in case c-359/12 Michael Timmel v Aviso Zeta AG (ECLI:EU:C:2013:783), footnote 50.

${ }^{35}$ Judgment of the Court of 15.05.2014 in case c-359/12 Michael Timmel v Aviso Zeta AG (ECLI:EU:C:2014:325), point 63.

${ }^{36}$ Opinion of Advocate General J. Kokott delivered on 16.05.2013 in case C-298/12 Confédération paysanne v Ministre de l'alimentation, de l'agriculture et de la pêche (ECLI:EU:C:2013:319).
} 
to searching for traces of the intentions of the legislator in legislative materials, systematics, and aim of the regulation. Analysing the course of the legislative process, the Advocate General pointed out that the discrepancies in the language already existed at the proposal stage (in the Commission). Consequently, the legislative materials, although they did not resolve doubts, provided an indication of the legislator's intent. Further teleological and axiological considerations ${ }^{37}$ led the Advocate General to the formulation of proposals for resolving the dispute. The Court shared the conclusions of the AG, conducting an even more detailed analysis of the legislative work, systematics and the preamble to the contested regulation ${ }^{38}$. Therefore, the historical argument served in the initial phase and was further supported by other means of interpretation. Together with the quantitative argument it might be seen as a valuable help to choose from different interpretative possibilities, similar to the previously explained national practice.

\section{Conclusions}

The usage of legislative history in interpretation of the EU and Polish national law differs significantly.

1. In Polish judgments two different roles of historical arguments can be distinguished - sometimes they are used to determine the lawmaker's intent and in other cases they serve to explain the meaning of particular expressions. In contrast, in the CJEU legislative history is often employed to establish the language version that has been subject to legislative works and negotiations or to distinguish between unofficial originals and subsequent language versions.

2. Moreover, in interpretation of the EU legislation the travaux preparatoires serve rather at the beginning of the whole process,

${ }^{37}$ Opinion of Advocate General J. Kokott delivered on 16.05.2013 in case C-298/12 Confédération paysanne $\mathrm{v}$ Ministre de l'alimentation, de l'agriculture et de la pêche (ECLI:EU:C:2013:319), points 25-34

38 Judgment of the Court of 3.10.2013 in case C-298/12 Confédération paysanne v Ministre de l'Alimentation, de l'Agriculture et de la Pêche (ECLI:EU:C:2013:630), points 21-34 
determining the scope of further linguistic analyses and supporting other argumentation, whereas in Poland they can play five different roles, from verifying and supplementing other arguments up to decisive function in cases of interpretation against the wording. The latter is less possible in the multilingual EU reality, where the existence of many language versions of the interpreted act significantly weakens the possibility of achieving interpretation incompatible with the wording (due to the multiplicity of alternative understandings of the disputed expression, consistent with at least one authentic language version).

3. The analysis of the relation between linguistic comparison and arguments based on history of legislation shows that multilingualism of EU law implies the increasing interest of the Court of Justice in historical method of interpretation.

4. Changes in the number of official EU languages imply the possibility to refer to the chronology of the formation of following language versions of the interpreted act, which in some cases leads to a limitation of the scope of the linguistic comparison. In other cases the compatibility of chosen interpretation with the original language versions serves as an argument in favour of the final decision.

\section{Bibliography}

Andrzejewska-Czernek, Izabela. 2013. Wykładnia prawa podatkowego Unii Europejskiej. Warszawa: Wolters Kluwer.

Bielska-Brodziak, Agnieszka.2017. Śladami prawodawcy faktycznego. Materiały legislacyjne jako narzędzie wykładni. Warszawa: Wolters Kluwer.

Bielska-Brodziak, Agnieszka. 2006. Orzecznictwo NSA w sprawach podatkowych. Językowa granica wykładni, Radca Prawny 2006, vol. 2: 78-87.

Bielska-Brodziak, Agnieszka. 2012. Materiały legislacyjne w dyskursie interpretacyjnym z perspektywy brytyjskiej, amerykańskiej, francuskiej, szwedzkiej i polskiej. In 
Konwergencja czy dywergencja kultur i systemów prawnych? ed. O. Nawrot, S.Sykuna, J. Zajadło, 144-154. Warszawa: C. H. Beck.

Bielska-Brodziak, Agnieszka. 2017. Śladamiprawodawcyfaktycznego. Materiały legislacyjne jako narzędzie wykładni, Warszawa: Wolters Kluwer.

Breyer, Stephen.1992. On the uses of legislative history in interpreting statutes. Southern California Law Review 65: 845-874.

Brudney James J. 2011. Confirmatory Legislative History. Brooklyn Law Review 76: 90-914.

Doczekalska, Agnieszka 2006. Interpretacja wielojęzycznego prawa Unii Europejskiej. Europejski Przeglad Sadowy 5: 14-21.

Doczekalska, Agnieszka. 2009b. Drafting or Translation. Production of Multilingual Legal Texts. In Translation Issues in Language and Law. Ed. F. Olsen,R. Lorz,D. Stein, 116-135 Basingstoke/New York: Palgrave Macmillan Ltd.

Doczekalska, Agnieszka.2009a. Drafting and interpretation of EU law - paradoxes of legal multilingualism. In Formal linguistics and law. ed. G. Grewendorf, M. Rathert, 339-370. Berlin, New Jork. Mouton de Gruyter.

Edincott, Timothy A. O. 2011. The Value of Vagueness. In Philosophical Foundations of Language in Law, ed. A. Marmor, S. Soames. Oxford: Oxford University Press, 14- 30. Eskridge Jr, William N., Philipp P. Frickey, Elisabeth Garrett.2006. Legislation and Statutory Interpretation. New York: Foundation Press.

Gizbert-Studnicki, Tomasz. 1978. Wieloznaczność leksykalna w interpretacjiprawniczej.Kraków:Wydawnictwo Uniwersytetu Jagiellońskiego.

Gluck, Abbe R. and Lisa Schultz Bressman. 2013. Statutory Interpretation from the Inside - An Empirical Study of Congressional Drafting, Delegation, and the Canons, Part I. Stanford Law Review 65: 901-1025.

Gluck, Abbe R. and Lisa Schultz Bressman. 2013. Statutory Interpretation from the Inside - An Empirical Study of Congressional Drafting, Delegation, and the Canons, Part II. Stanford Law Review 66: 725-801. 
Grabowski, Andrzej. 1997. Pragmatyczna charakterystyka odróżnienia problemu interpretacji i problemu klasyfikacji w koncepcji N. MacCormicka. In Filozoficzno-teoretyczne problemy sadowego stosowania prawa. XII Ogólnopolski Zjazd Katedr Teorii i Filozofii Prawa (Łódź, 8-10 listopada 1996 r.), ed. M. Zirk-Sadowski, 85-89. Łódź: Wydawnictwo Uniwersytetu Łódzkiego.

Greenawalt, Kent. 2001. Vagueness and Judicial Responses to Legal Indeterminacy. Legal Theory 7: 433-445.

Jellum, Linda D. 2008. Mastering Statutory Interpretation. Durham: Carolina Academic Press.

Jónsson, Ólafur Páll. 2009. Vagueness. Interpretation and the Law. Legal Theory 15: 193-214.

Lenaerts, Koen and José A. Gutiérrez-Fons. 2013. To say what the law of the EU is: methods of interpretation and the European Court of Justice. EUI Working Papers AEL 9: 2-48.

Łętowska, Ewa. 2011. Interpretacja a subsumpcja zwrotów niedookreślonych i nieostrych, Państwo i Prawo 7-8: 17-29.

MacCormick, Neil. 1978. Legal Reasoning and Legal Theory, Oxford: Oxford University Press.

Mammen, Christian E. 2002. Using Legislative History in American Statutory Interpretation, Hague-London-New York: Kluwer Law International.

Miettinen, Samuli and Merita Kettunen. 2005. Travaux to the Treaties: Treasures or trivia?, 2005, conference paper published online at

https://eustudies.org/conference/papers/11?criteria=author\&pa ge $=7$ (accessed 31.08.2017).

Nourse, Victoria F. 2014. Elementary Statutory Interpretation: Rethinking Legislative Intent and History. Boston College Law Review 55: 1613-1658.

Popkin jr., William D. 2007. A Dictionary of Statutory Interpretation. Durham: Carolina Academic Press.

Reich, Norbert, Christopher Goddard and Ksenija Vasiljeva. 2004. Understanding EU Law: Objectives, Principles and Methods of Community Law. Oxford: Oxford University Press.

Schønberg, Soren and Karin Frick. 2003. Finishing, Refining, Polishing: On the Use of travaux preparatoires as an Aid to the 
Interpretation of Community Legislation. European Law Review 28: 149-169.

Schultz Bressman, Lisa. 2014. Statutory Interpretation from the Inside - An Empirical Study of Congressional Drafting, Delegation, and the Canons..., Part II, Stanford Law Review 66: 725-801.

Solan, Lawrence M. 2005. Private Language, Public Laws: The Central Role of Legislative Intent in Statutory Interpretation. Georgetown Law Journal 93: 427-486.

Spyra, Tomasz 2006. Granice wykładni prawa. Znaczenie językowe tekstu prawnego jako granica wykładni. Warszawa: Wolters Kluwer.

Tobor, Zygmunt. 2013. W poszukiwaniu intencji prawodawcy. Warszawa: Wolters Kluwer Polska.

Tobor, Zygmunt. 2010. Iluzja wykładni językowej. In Konstytucyjne uwarunkowania tworzenia $i$ stosowania prawa finansowego $i$ podatkowego, ed. P. J. Lewkowicz, J.Stankiewicz. Białystok: Temida 2: 194-201.

Übelacker, Michael. 1993. Die genetische Auslegung in der jüngeren Rechtsprechung des Bundesverfassungsgerichts. $\mathrm{PhD}$ Diss: Kiel. Christian-Albrechts-Universität.

Zeppos, Nicholas S. 1990. Legislative History and the Interpretation of Statutes: Toward a Fact-Finding Model of Statutory Interpretation. Virginia Law Review 76: 1295-1374.

Zirk-Sadowski, Marek. 2012. Wpływ orzecznictwa Trybunału Sprawiedliwości Unii Europejskiej na wykładnię sądów administracyjnych. In System prawa administracyjnego, ed. R. Hauser, Z. Niewiadomski, A. Wróbel. vol.4. 412-431. Warszawa: C.H. Beck.

\section{Polish case law cited}

Resolution of the Polish Supreme Court from 25.02.2009 in case I KZP $39 / 08$.

Judgment of Voivodeship Administrative Court in Cracow from 28.11.2013 in case I SA/Kr 1222/13, LEX nr 1485017.

Judgment of Voivodeship Administrative Court in Cracow from 06.06.2013 in case I SA/Kr 1903/12, LEX nr 1333935.

Judgment of Supreme Administrative Court in Warsaw from 26.02.2013 in case I FSK 491/12, LEX nr 1354026. 
Resolution of the Polish Supreme Court from 26.04. 2007 in case I KZP 7/07, OSNKW 2007/5/38.

\section{EU case law cited}

Judgment of the Court of 23.02. 1988 r. in case C- 429/85 Commission v Italy, Rec. p. 843.

Judgment of the Court of 10.01.2006 in case C- 402/03 Skov Æg v Bilka Lavprisvarehus A/S and Bilka Lavprisvarehus A/S v Jette Mikkelsen and Michael Due Nielsen (ECLI:EU:C:2006:6) point 42.

Opinion of Advocate General P. Mengozzi from 24.10.2012 in case C409/11 Csonka and others v. Magyar Állam (ECLI:EU:C:2012:660).

Judgment of the Court from 26.09.2013 in case C-193/11 European Commission against Republic of Poland (ECLI:EU:C:2013:608, point 15).

Opinion of Advocate General P. Cruz Villalón from 06.10.2015 $\mathrm{r}$ in joined cases C-443/14 and C-444/14 Kreis Warendorf v. Ibrahim Alo and Amira Osso v. Region Hannover (ECLI:EU:C:2015:665).

Opinion of Advocate General E.Sharpston delivered on 26.11.2013 in case C-359/12 Michael Timmel $v$ Aviso Zeta AG (ECLI:EU:C:2013:783).

Judgment of the Court of 15.05.2014 in case c-359/12 Michael Timmel v Aviso Zeta AG(ECLI:EU:C:2014:325).

Opinion of Advocate General J. Kokott delivered on 16.05.2013 in case C-298/12 Confédération paysanne v Ministre de l'alimentation, de l'agriculture et de la pêche (ECLI:EU:C:2013:319).

Judgment of the Court of 3.10.2013 in case C-298/12 Confédération paysanne v Ministre de l'Alimentation, de l'Agriculture et de la Pêche (ECLI:EU:C:2013:630).

Judgment of the Court of 26.02.1991r. in case C-292/89 The Queen v Immigration Appeal Tribunal, ex parte Gustaff Desiderius Antonissen (ECLI:EU:C:1991:80). 